\title{
Real-Time PCR Systems Targeting Giant Viruses of Amoebae and Their Virophages
}

\author{
Tatsiana Ngounga $^{\text {a }}$ Isabelle Pagnier ${ }^{a}$ Dorine-Gaelle Ikanga Reteno ${ }^{a}$ \\ Didier Raoult ${ }^{a-c}$ Bernard La Scola ${ }^{a, b}$ Philippe Colson ${ }^{a, b}$
}

aUnité de Recherche sur les Maladies Infectieuses et Tropicales Emergentes (URMITE) UM63, CNRS 7278, IRD 198, INSERM U1095, Facultés de Médecine et de Pharmacie, Aix-Marseille Université, and 'b Institut Hospitalo-Universitaire Méditerranée Infection, Pôle des Maladies Infectieuses et Tropicales Clinique et Biologique, Fédération de Bactériologie-Hygiène-Virologie, Centre Hospitalo-Universitaire Timone, Assistance Publique-Hôpitaux de Marseille, Marseille, France; ${ }^{c}$ Special Infectious Agents Unit, King Abdulaziz University, Jeddah, Saudi Arabia

\section{Key Words}

Mimivirus · Marseillevirus · Giant virus · Virophage ·

Sputnik · Real-time PCR · Mimiviridae · Marseilleviridae ·

Megavirales $\cdot$ Amoeba

\begin{abstract}
Giant viruses that infect amoebae, including mimiviruses and marseilleviruses, were first described in 2003. Virophages were subsequently described that infect mimiviruses. Culture isolation with Acanthamoeba spp. and metagenomic studies have shown that these giant viruses are common inhabitants of our biosphere and have enabled the recent detection of these viruses in human samples. However, the genomes of these viruses display substantial genetic diversity, making it a challenge to examine their presence in environmental and clinical samples using conventional and realtime PCR. We designed and evaluated the performance of PCR systems capable of detecting all currently isolated mimiviruses, marseilleviruses and virophages to assess their prevalence in various samples. Our real-time PCR assays accurately detected all or most of the members of the currently delineated lineages of giant viruses infecting acanthamoebae as well as the mimivirus virophages, and enabled
\end{abstract}

accurate classification of the mimiviruses of amoebae in lineages $A, B$ or $C$. We were able to detect four new mimiviruses directly from environmental samples and correctly classified these viruses within mimivirus lineage $C$. This was subsequently confirmed by culture on amoebae followed by partial Sanger sequencing. PCR systems such as those implemented here may contribute to an improved understanding of the prevalence of mimiviruses, their virophages and marseilleviruses in humans.

ㄷ) 2013 S. Karger AG, Basel

\section{Introduction}

Giant viruses of amoeba were first described in 2003 by our laboratory, with the discovery of Acanthamoeba polyphaga mimivirus in water collected in 1992 from a cooling tower in England $[1,2]$. Other mimiviruses were subsequently isolated, primarily from environmental water or soil samples [3-7]. Mimiviruses are larger than some bacteria and encode approximately 1,000 proteins, including some that are unique amongst viruses $[1,8]$. These giant viruses that were isolated by co-culture with Acanthamoeba spp. have been classified within 3 lineages:

\begin{tabular}{ll}
\hline KARGER & $\begin{array}{l}\text { ( ) 2013 S. Karger AG, Basel } \\
0300-5526 / 13 / 0566-0413 \$ 38.00 / 0 \quad \text { Karger }\end{array}$ \\
$\begin{array}{l}\text { E-Mail karger@karger.com } \\
\text { www.karger.com/int }\end{array}$ & $\begin{array}{l}\text { This is an Open Access article licensed under the terms of the } \\
\text { Creative Commons Attribution-NonCommercial 3.0 Un- } \\
\text { ported license (CC BY-NC) (www.karger.com/OA-license), } \\
\text { applicable to the online version of the article only. Distribu- } \\
\text { tion permitted for non-commercial purposes only. }\end{array}$
\end{tabular}




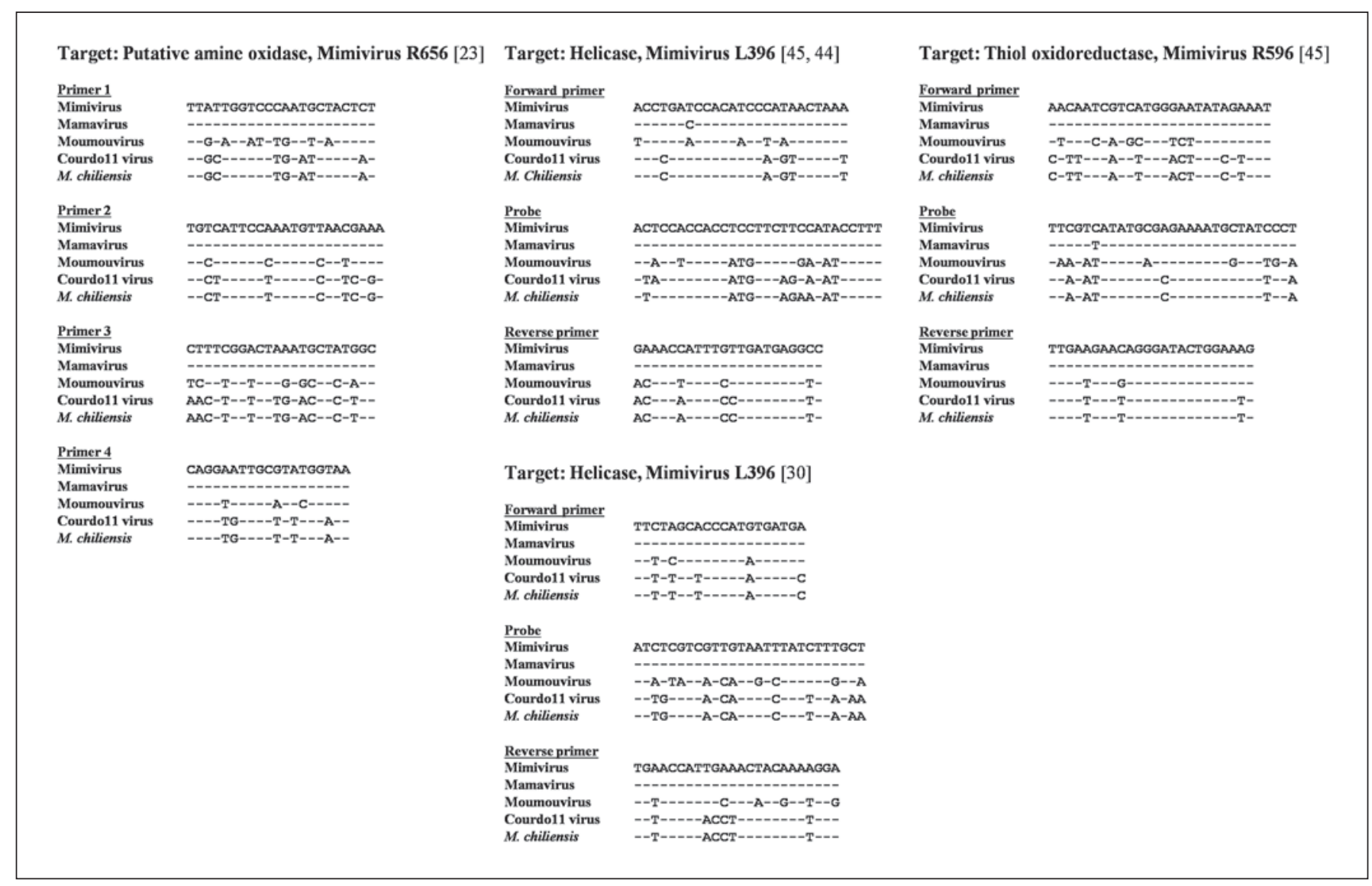

Fig. 1. In silico analyses showing mismatches in the primers and probes used in previous studies that aimed at detecting Mimivirus by PCR from clinical samples. Mismatches between the primers and probes used (at the top, underlined) and the genome sequenc-

$\mathrm{A}, \mathrm{B}$ and $\mathrm{C}[9,10]$. In addition, Cafeteria roenbergensis virus (Crov), a more distantly related mimivirus, has been recovered from a marine dinoflagellate [5], and the family Mimiviridae continues to expand [11]. Furthermore, mimiviruses can themselves be infected by viruses called virophages, similarly to eukaryotes, bacteria and archaea, and have been shown to harbor a specific mobilome [10, 12]. Other giant viruses isolated using amoebal culture have been recovered from water and have been classified in the proposed family 'Marseilleviridae' that encompasses Marseillevirus, its founding member, Lausannevirus, and other members including Tunisvirus fontaine $2[6,13,14]$. Mimiviruses and marseilleviruses have been classified as members of the superfamily of large nucleocytoplasmic DNA viruses, NCLDVs $[15,16]$, for which we recently proposed a reclassification into a new order 'Megavirales' [9].

Members of families Mimiviridae and 'Marseilleviridae' appear to be common in our environment. In fact, es of Mimivirus, Mamavirus, Moumouvirus and LBA111 are indicated by nucleotides. Dashes indicate that the nucleotide is identical, asterisks indicate that the nucleotide is absent.

metagenomic studies have revealed the presence of sequences similar to Mimivirus genomic DNA in environmental samples [17-21]. In addition, mimiviruses or marseilleviruses have been isolated from up to $20 \%$ of water samples tested, as well as from soil samples, collected from various geographical areas using optimized protocols for coculturing on Acanthamoeba spp. [3, 6], which suggests that humans might be frequently exposed to these viruses. Furthermore, there is considerable evidence that Mimivirus is a causative agent of pneumonia [22]. This virus can survive and multiply in acanthamoebae, as can other human pathogens that cause pneumonia, including Legionella pneumophila [23-26]. In the clinic, antibody responses to Mimivirus have been observed in pneumonia patients, in whom the Mimivirus seroprevalence was greater than in control patients [23, 27-31]. Antibodies to the virophage were detected in 2 patients with unexplained fever, and seroconversion could be demonstrated in 1 of 
these cases [32]. In addition, new mimiviruses, named Lentille virus and LBA111, have been recovered from contact lens storage case liquid and the bronchoalveolar fluid of a Tunisian patient presenting with pneumonia, respectively $[33,34]$. Besides, sequences matching DNA from mimiviruses and virophages have been detected in metagenomes of human respiratory samples or feces [35-39]. Experimentally, mice intratracheally inoculated with Mimivirus exhibited pneumonia and the virus was observed in the lungs of the mice [40]. Mimivirus was also able to infect macrophages [41]. With regard to marseilleviruses, two new members of this group, named Senegalvirus and Giant Blood Marseillevirus, have been isolated from feces and blood collected from a young man living in rural Senegal and a blood donor in Marseille, respectively [39, 42, 43]. Both individuals had no clinical symptom, which suggests that these viruses may be carried in healthy subjects. In addition, among 20 blood donors, 3 were seropositive for Giant Blood Marseillevirus, and this virus was detectable by PCR in 2 of these individuals [43]. Taken together, these findings suggest the need to expand searches for the presence of amoebae-associated giant viruses in clinical samples to gain a better insight into the pathogenicity of these viruses in humans.

Mimivirus has been detected by PCR only twice from the bronchoalveolar fluid of pneumonia patients [23,34]. Four studies conducted by different teams that in some cases used identical PCR systems failed to detect Mimivirus DNA in pneumonia patients [44-47]. This contrasts with the frequent detection of antibodies to Mimivirus using in-house assays and suggests that serology might detect cross-reactivity against close Mimivirus relatives whereas Mimivirus DNA detection is hampered by the considerable genetic diversity of mimiviruses of amoebae $[23,27,29-32,43]$. Thus, the three PCR systems used in these studies may have failed to detect other mimiviruses because all had been designed using the Mimivirus genome sequence generated in 2004 [25, 26, 34]. In silico analyses clearly show a substantial number of mismatches with genomes of other mimiviruses in the primers and probes used in these PCR investigations (fig. 1), and these mismatches likely prevented the detection of any mimiviruses other than the initial strain in clinical samples. It appears that the genomes of Marseillevirus and the mimivirus virophages can also display considerable genetic diversity in some regions, and the three published Marseillevirus genomes tentatively show the existence of two or three different lineages $[6,10,48]$. It is notable that in studies aiming to diagnose infections with giant viruses of amoebae and virophages that used both PCR and
Table 1. Collection of the viruses of amoebae available in our laboratory and tested with the five real-time PCR systems

\begin{tabular}{|c|c|c|}
\hline Family & Lineage & Virus \\
\hline \multirow[t]{3}{*}{ Mimiviridae } & $\mathrm{A}$ & $\begin{array}{l}\text { Mimivirus } \\
\text { Mamavirus } \\
\text { Terra } 2 \\
\text { Pointe rouge } 1 \\
\text { Pointe rouge } 2 \\
\text { Cher } \\
\text { Fauteuil } \\
\text { Longchamps } \\
\text { Lactour } \\
\text { Lentille } \\
\text { Marais } \\
\text { Univirus } \\
\text { Sangsue }\end{array}$ \\
\hline & B & $\begin{array}{l}\text { Moumouvirus } \\
\text { Monve } \\
\text { Ochan } \\
\text { Goulette }\end{array}$ \\
\hline & $\mathrm{C}$ & $\begin{array}{l}\text { Montpellier } \\
\text { Courdo } 11 \\
\text { Courdo } 7 \\
\text { Courdo } 5 \\
\text { Terra } 1 \\
\text { Bus } \\
\text { LBA } 111 \\
\text { Mont } 1 \\
\text { Shan }\end{array}$ \\
\hline Marseilleviridae & & $\begin{array}{l}\text { Marseillevirus } \\
\text { Cannes } 8 \\
\text { Senegal-virus } \\
\text { Fontaine Saint-Charles } \\
\text { Tunis-virus fontaine } 2\end{array}$ \\
\hline Virophage & & Sputnik 1 \\
\hline
\end{tabular}

serology, serology was more frequently positive than PCR $[23,30,32,43]$. Therefore, the present study aimed to design and evaluate PCR systems capable of detecting all currently isolated mimiviruses, marseilleviruses and virophages to assess their prevalence in clinical samples.

\section{Materials and Methods}

Collection of Giant Viruses and Control Samples

To develop real-time PCR systems and assess their sensitivity and specificity, we used positive controls that consisted of culture supernatants of a collection of giant viruses isolated in our laboratory by co-culture on Acanthamoeba spp., the genomes of which have been sequenced [3,49] (table 1). Classification within previ- 
Fig. 2. Schematic diagram of the strategy to design primers and probes for real-time PCR systems targeting the three major lineages of mimiviruses, their virophages and marseilleviruses.

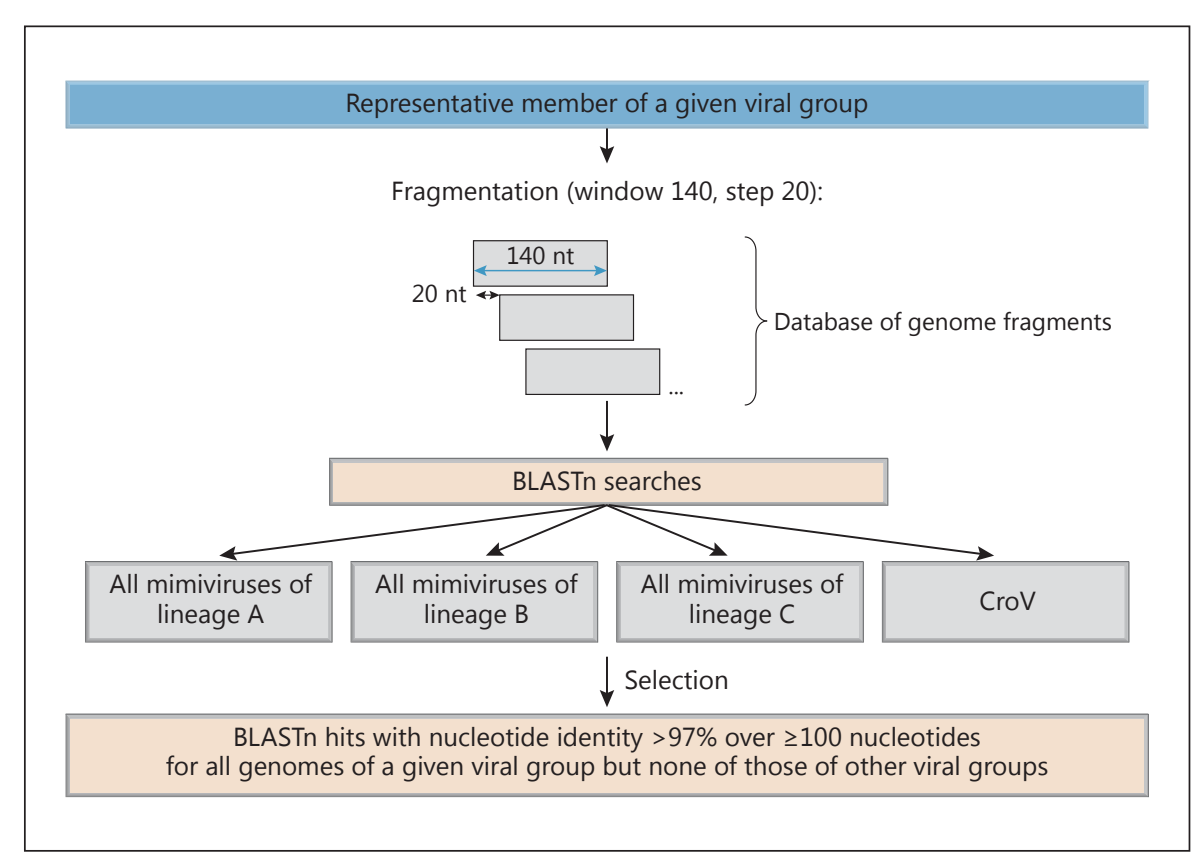

ously established mimivirus lineages A, B or C $[9,10]$ was determined by analyses of conserved genes including the gene encoding the family B DNA polymerase [3]. Virus-free culture supernatants from $A$. polyphaga were included as negative controls.

Recombinant pUC 57 plasmids (Eurogentec, Liège, Belgium) were used as quantification standards, as positive controls and to evaluate the detection limit of the real-time PCR assays. One plasmid was designed for use in PCR systems for detecting mimiviruses (lineages A, B and C) and marseilleviruses. A second plasmid was designed for PCR systems dedicated to virophages. Each of the viral genomic DNA fragments targeted by the PCR systems were inserted into the plasmids, and NotI or XhoI restriction sites were inserted into the sequences of the amplicon to allow diagnostic digests of these plasmids in case of suspected contamination.

In addition, a total of 68 environmental samples were tested. Most of these samples were water samples: 32 samples consisted of stagnant water, 5 samples of water collected from decorative fountains, 4 samples were collected from public pumps, 3 were from rivers, 8 from streams, 2 from hospitals, 4 samples were from domestic water and 2 were seawater samples. Additionally, 8 soil samples were tested.

\section{DNA Extraction}

Viral DNA was extracted with the automated EZ1 Virus MiniKit v.2 kit (Qiagen GmbH, Hilden, Germany) according to the manufacturer's instructions. Extractions were performed using $200 \mu \mathrm{l}$ of culture supernatants or $400 \mu \mathrm{l}$ of water samples. For soil samples, $100 \mathrm{~g}$ of soil was diluted in $50 \mathrm{ml}$ of sterile water, vortexed and allowed to settle before decanting. Thereafter, DNA was extracted from $400 \mu \mathrm{l}$ of the supernatant.

Design of Primers and Probes for the Real-Time PCR Systems

We used a new strategy to design primers and probes for realtime PCR systems targeting the three major lineages of mimivi- ruses, their virophages, and marseilleviruses (fig. 2). First, we divided the genome of one representative member of each of the viral groups (mimivirus lineages $\mathrm{A}, \mathrm{B}$ and $\mathrm{C}$; marseilleviruses; virophages) into windows of 140 nucleotides with steps of $20 \mathrm{nu}$ cleotides, which are in the order of magnitude of usual sizes in real-time PCR assays of amplified fragments and PCR oligos, respectively. Genomes that were analyzed were those of amoebaeassociated viruses previously described $[4,8,13,49,50]$ and those sequenced from giant viruses isolated in our laboratory $[3,10]$. Next, we created a database of all genomes of each of the viral groups and performed a local BLASTn search for 140-nucleotide-long fragments against this genome database. Then we selected appropriate fragments using the following rules: the fragments needed to match at least one fragment from each of the genomes of the viral group with $97 \%$ nucleotide identity over at least 100 contiguous nucleotides and the fragments needed to show no significant nucleotide identity with any of the genomes belonging to other viral groups. Following the identification of a genomic fragment, this fragment was aligned using ClustalX v1.8 [51] with its counterparts in other genomes of the viral group. Following this step, traditional primer and probe design was performed using SVARAP and Primer3 [52, 53]. The sequences of the primers and probes designed using this approach are presented in table 2 .

\section{Real-Time PCR Assay Protocols}

We implemented five real-time PCR systems based on hydrolysis probes. Tests were performed using the QuantiTec Probe PCR kit (Qiagen). The concentrations of primers and probes were optimized for each PCR system individually using various concentrations of oligos or a temperature gradient. PCR reactions consisted of $5 \mu \mathrm{l}$ of extracted DNA in an amplification reaction mix containing $12.5 \mu \mathrm{l}$ of $2 \mathrm{X}$ QuantiTec Probe PCR Master Mix, $0.5 \mu \mathrm{l}$ of probe at $1 \mathrm{pmol} / \mu \mathrm{l}$, and $0.5 \mu \mathrm{l}(0.2 \mu \mathrm{M})$ of 
forward and reverse primers for assays for lineage $\mathrm{B}$ mimiviruses, marseilleviruses and Sputnik virophages, or $1 \mu \mathrm{l}(0.4 \mu \mathrm{M})$ of forward and reverse primers for assays for lineage $\mathrm{A}$ and $\mathrm{C}$ mimiviruses. PCR reactions were adjusted to a final volume of $25 \mu \mathrm{l}$ by adding RNAse/DNAse-free water. PCR reactions were performed on a CFX96TM real-time system instrument (Bio-Rad, Hercules, Calif., USA). The PCR amplification protocol was as follows: a step at $95^{\circ}$ for 15 min followed by 45 cycles of denaturation at $95^{\circ}$ for $30 \mathrm{~s}$ and annealing/extension at $60^{\circ}$ for $1 \mathrm{~min}$. All samples and controls were tested once in a first step of the analysis and then samples testing positive were retested under the same conditions to assess reproducibility of detection. Samples reproducibly testing positive were inoculated on amoebae according to the previously described protocol [3] and the culture supernatants were retested by real-time PCR. In addition, these samples were purified using NucleoFast plates (Macherey-Nagel GmbH \& Co. KG, Düren, Germany) then sequenced using the PCR primers used in the real-time PCR assay with an ABI PRISM BigDye Terminator v3.1 Cycle Sequencing Kit (Applied Biosystems, Foster City, Calif., USA) according to the manufacturer's instructions.

\section{Determination of Sensitivity and Specificity of Detection}

The sensitivity and specificity of detection of each of the realtime PCR systems was determined by testing a panel of viruses infecting amoebae (table 1).

\section{Determination of Detection Threshold}

The detection limit of each real-time PCR system was assessed for all viruses, including 13 mimiviruses from group A, 4 mimiviruses from group B, 9 mimiviruses from group C, 5 marseilleviruses and for the Sputnik 1 virophage (table 1). The number of copies of the quantification plasmids was calculated by spectrophotometry. To determine the limit of detection for each PCR system, we first performed serial dilutions of samples at 1:10 dilutions between $10^{7}$ copies and 1 copy per reaction, and tested these samples in quadruplicate. Then, serial 1:2 dilutions of samples were generated starting using $10^{3}$ copies/PCR reaction for systems A and $\mathrm{B}$ mimiviruses and $10^{2}$ copies/PCR reaction for system $\mathrm{C}$ mimiviruses, marseilleviruses and virophages. Each of these dilution points was tested ten times. Based on these results, standard curves were generated from the cycle threshold $(\mathrm{Ct})$ values obtained for each concentration.

\section{Culture of Giant Viruses and Their Virophages}

Culture on Acanthamoeba spp. of giant viruses and the virophage used in the present study to assess the performance of the PCR systems and to confirm the detection of these viruses from environmental samples was performed as previously described [3]. Briefly, for each virus, $30 \mathrm{ml}$ of $A$. polyphaga cultures were inoculated with $5 \mathrm{ml}$ of a previously frozen viral suspension and incubated at $32^{\circ}$ until complete lysis of the amoebae. For the virophage, the amoebal suspension was inoculated with both Mimivirus and the virophage. Viruses were then purified by filtration of the culture supernatant through $1.2-\mu \mathrm{m}$-pore filters for mimiviruses and $0.45-\mu \mathrm{m}$-pore filters for marseilleviruses and Sputnik, and kept frozen at $-80^{\circ}$ until use. Environmental samples tested for the presence of giant viruses were inoculated on a monolayer of $A$. polyphaga at $5 \times 10^{5}$ amoebae $/ \mathrm{ml}$. An antibiotic cocktail was added in order to prevent bacterial multiplication, as described elsewhere

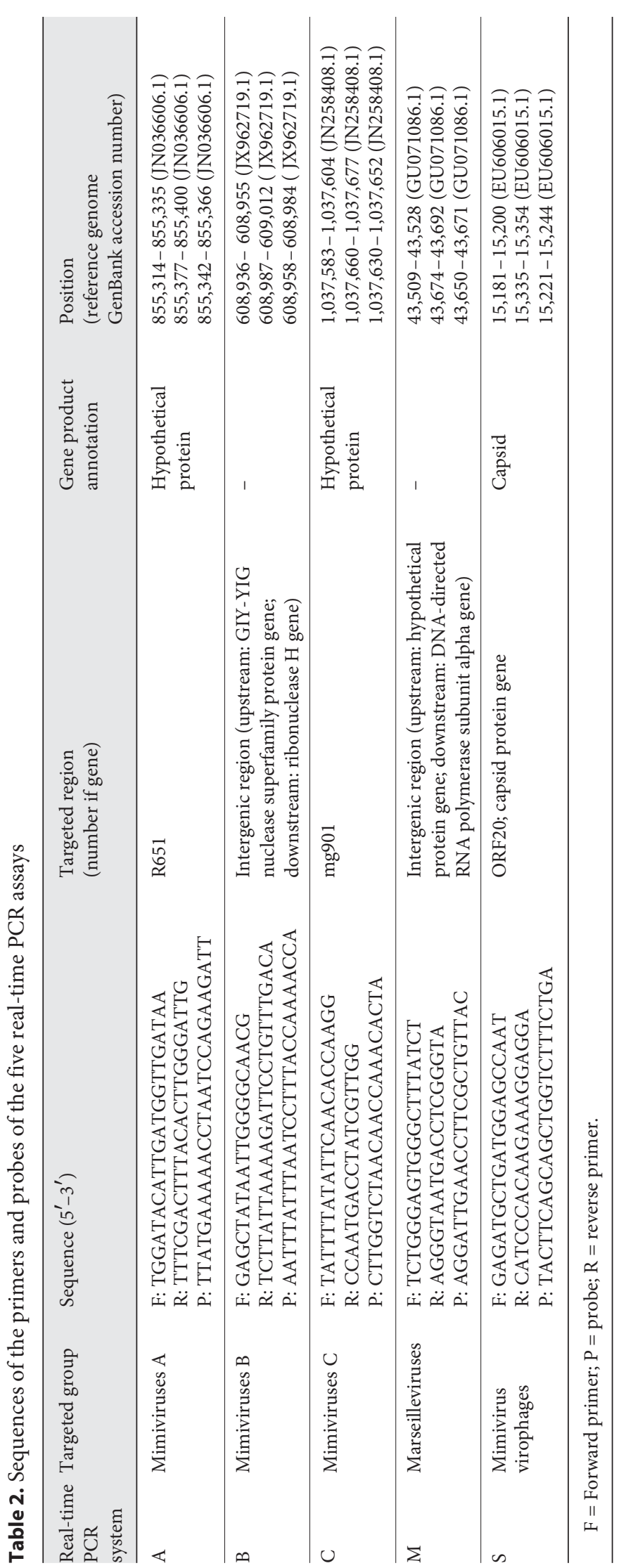

Intervirology 2013;56:413-423 DOI: $10.1159 / 000354563$ 
Table 3. Results of sensitivity and specificity testing for the five real-time PCR systems

\begin{tabular}{|c|c|c|c|c|c|}
\hline \multirow[t]{3}{*}{ Viruses } & \multicolumn{5}{|c|}{ Real-time qPCR system } \\
\hline & \multicolumn{3}{|c|}{ Mimiviridae } & \multirow{2}{*}{$\begin{array}{l}\text { Mar- } \\
\text { seille- } \\
\text { viridae }\end{array}$} & \multirow{2}{*}{$\begin{array}{l}\text { Sputnik } \\
\text { viro- } \\
\text { phage }\end{array}$} \\
\hline & A & B & $\mathrm{C}$ & & \\
\hline
\end{tabular}

\begin{tabular}{|c|c|c|c|c|c|}
\hline \multicolumn{6}{|l|}{ Mimiviridae } \\
\hline \multicolumn{6}{|l|}{ Lineage A } \\
\hline Mimivirus & 22.0 & ND & ND & $\mathrm{ND}$ & ND \\
\hline Mamavirus & 19.4 & ND & ND & 39.0 & 29.4 \\
\hline Terra 2 & 23.2 & ND & ND & ND & ND \\
\hline Pointe rouge 1 & 22.4 & ND & ND & ND & ND \\
\hline Pointe rouge 2 & 20.9 & ND & ND & ND & ND \\
\hline Cher & 23.3 & ND & ND & ND & ND \\
\hline Fauteuil & 22.0 & ND & $\mathrm{ND}$ & 19.2 & $\mathrm{ND}$ \\
\hline Longchamps & 21.7 & ND & ND & ND & ND \\
\hline Lactour & 23.0 & ND & ND & ND & ND \\
\hline Lentille & 18.6 & ND & ND & ND & 11.8 \\
\hline Marais & 20.7 & ND & ND & ND & ND \\
\hline Univirus & 22.0 & ND & ND & ND & ND \\
\hline Sangsue & 22.4 & ND & ND & ND & ND \\
\hline \multicolumn{6}{|l|}{ Lineage B } \\
\hline Moumouvirus & $\mathrm{ND}$ & 25.5 & $\mathrm{ND}$ & $\mathrm{ND}$ & $\mathrm{ND}$ \\
\hline Monve & ND & 21.9 & $\mathrm{ND}$ & ND & $\mathrm{ND}$ \\
\hline Ochan & ND & ND & ND & ND & ND \\
\hline Goulette & ND & ND & ND & ND & ND \\
\hline \multicolumn{6}{|l|}{ Lineage C } \\
\hline Montpellier & ND & ND & 26.9 & ND & ND \\
\hline Courdo 11 & ND & ND & 27.4 & ND & ND \\
\hline Courdo 7 & ND & $\mathrm{ND}$ & 26.0 & 21.4 & $\mathrm{ND}$ \\
\hline Courdo 5 & ND & ND & 26.3 & $\mathrm{ND}$ & ND \\
\hline Terra 1 & ND & ND & 24.9 & 38.0 & ND \\
\hline Bus & ND & ND & 26.8 & 36.5 & ND \\
\hline LBA 111 & ND & ND & 21.8 & ND & ND \\
\hline Mont 1 & ND & ND & 25.8 & ND & ND \\
\hline Shan & ND & ND & 24.4 & ND & ND \\
\hline \multicolumn{6}{|l|}{ Marseilleviridae } \\
\hline Marseillevirus & ND & ND & ND & 19.8 & $\mathrm{ND}$ \\
\hline Cannes 8 & ND & ND & ND & 15.5 & ND \\
\hline Senegal virus & ND & ND & $\mathrm{ND}$ & 14.0 & ND \\
\hline Fontaine Saint-Charles & ND & ND & ND & 14.5 & ND \\
\hline Tunisvirus fontaine 2 & ND & ND & ND & 12.4 & ND \\
\hline \multicolumn{6}{|l|}{ Virophage } \\
\hline Sputnik & 34.0 & ND & $\mathrm{ND}$ & ND & 22.2 \\
\hline
\end{tabular}

ND $=$ Not detected

[7]. Lysis of amoebae was determined under an inverted microscope and, when the presence of the virus was suspected, slides were prepared by cytocentrifugation and stained with Hemacolor to see the presence of viral factories in the cytoplasm of the amoebae. The presence of the giant virus in the amoebal culture was then confirmed by negative staining with a $3 \%$ suspension of ammonium molybdate and observation under an electron microscope.
Sanger Sequencing of Fragments of the Family B DNA

Polymerase Gene and the Capsid Gene

To check for the presence of mimiviruses and marseilleviruses in samples testing positive for viruses by our real-time PCR systems, and for the classification of these viruses within Mimivirus lineages, we generated fragments of the family B DNA polymerase and the capsid genes using conventional PCR amplification followed by Sanger population sequencing of these fragments, as described previously $[3,6]$.

\section{Results}

\section{Real-Time PCR Systems}

One primary real-time PCR system and two alternative systems were designed for each of the defined groups of viruses. Target regions amplified by PCR encompassed either genes or intergenic regions. For instance, the PCR systems for mimiviruses of lineage $A$ and $B$ target a hypothetical protein and an intergenic region, respectively (table 2).

\section{Specificity}

None of the real-time PCR systems resulted in an amplification signal for viruses other than those classified within the group that they were designed to target with the exception of the marseilleviruses system, which led to amplification of two mimiviruses from lineage A (Mamavirus and Fauteuil virus) and three mimiviruses from lineage $C$ (Courdo 7 virus, Terral virus and Bus virus). The $\mathrm{Ct}$ values measured for these amplifications were 39, 19, 21, 38 and 37, respectively (table 3 ). Conventional PCR amplification and Sanger sequencing of the genomic region encoding the capsid protein of marseilleviruses were performed for these 5 samples. Culture supernatants of Fauteuil virus and Courdo 7 virus were confirmed to contain Marseillevirus DNA. Our in silico analysis did not identify sequence similarity among the primers and probe used in the real-time PCR system and the genomes of the five mimiviruses mentioned above. In addition, the Mamavirus and Lentille virus culture supernatants tested positive using the virophage system, but these cultures were known to contain Mimivirus virophages.

\section{Sensitivity}

Real-time PCR systems used for detection of mimiviruses of lineage $\mathrm{A}$, mimiviruses of lineage $\mathrm{C}$, marseilleviruses and virophages allowed us to detect all of the viruses that belong to these groups that were available in our collection with Ct values ranging from 12.4 to 27.4 (table 4). The systems designed to detect mimiviruses of lineage $B$ only detected 2 of the 4 viruses tested from this lineage with Ct values lower than 30, while another system detected all four viruses from this lineage but with $\mathrm{Ct}$ values greater 

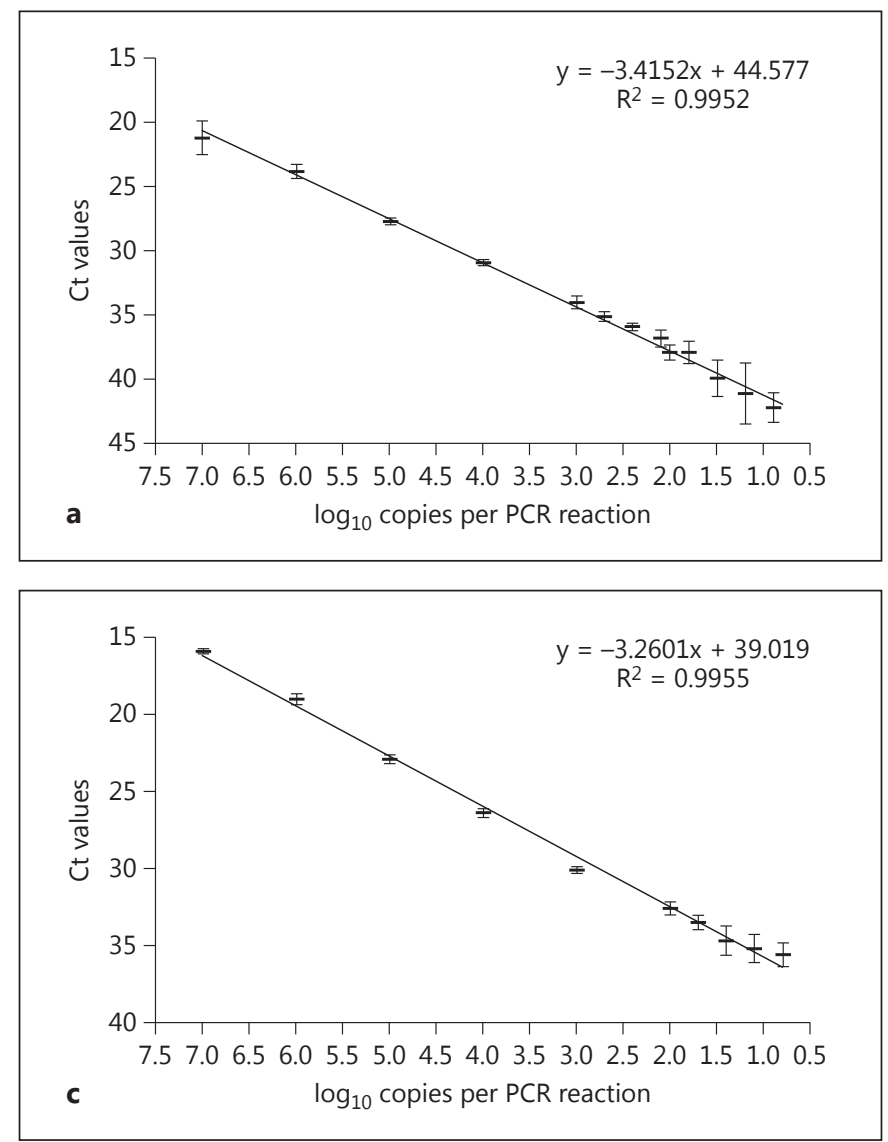

Fig. 3. Standard curves obtained with serial $1: 10$ and $1: 2$ dilutions starting with $10^{7}$ viral DNA copies per reaction using the five realtime qPCR systems: mimiviruses from lineage A (a), B (b) and C (c); marseilleviruses (d), and Sputnik virophage (e).

than 30. Quantitative analyses indicated that the detection limit of the system for mimiviruses from lineage A was approximately 60 copies per PCR reaction (table 4; fig. 3a-e). The detection limits for the systems for mimiviruses from lineage $B$, mimiviruses from lineage $C$ and marseilleviruses were approximately 20 copies per PCR. Using the system targeting Sputnik virophages, the limit of detection was approximately 10 copies per PCR reaction. Correlation coefficients were higher than 0.99 (fig. 3a-e).

PCR for Giant Viruses of Amoebae
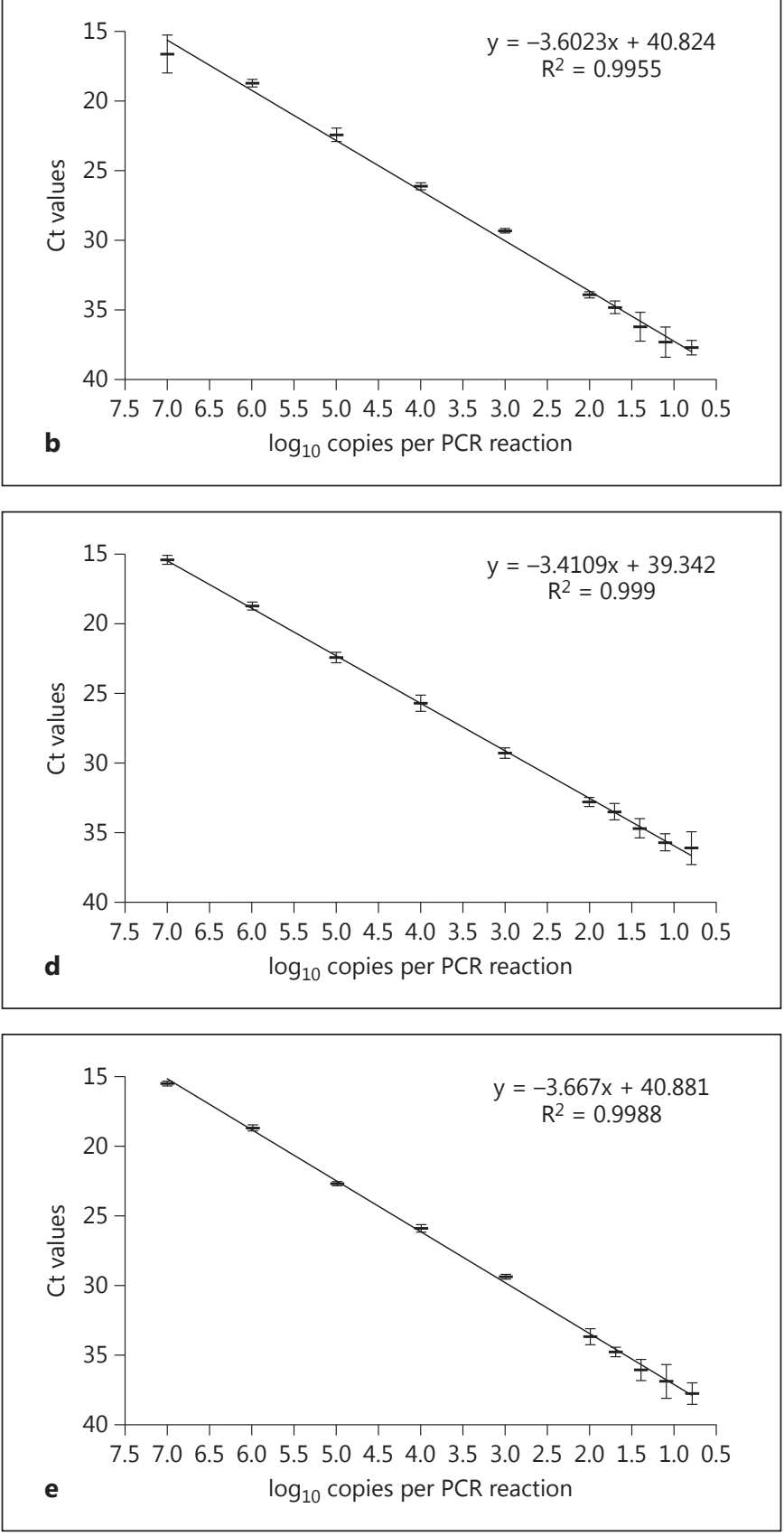

Assessment of the Capability of the Real-Time PCR Systems to Detect Amoebae Viruses in Environmental Samples

Among the 68 environmental samples tested, 4 (6\%), including 2 stagnant-water samples and 2 soil samples, were weakly positive for amoebae viruses by real-time PCR. These results were reproducible with average values of $39 \mathrm{Ct}$. Two of these samples (1 stagnant-water sample and 1 soil sample) were concurrently positive for marseil- 
Table 4. Results of detection threshold determination for the five real-time PCR systems

\begin{tabular}{|c|c|c|c|c|c|c|}
\hline \multicolumn{2}{|c|}{ Plasmid DNA concentrations } & \multicolumn{5}{|c|}{ Results of the real-time PCR system } \\
\hline \multirow{2}{*}{$\begin{array}{l}\text { DNA copies } \\
\text { per PCR reaction }\end{array}$} & \multirow{2}{*}{$\begin{array}{l}\log _{10} \text { DNA copies } \\
\text { per PCR reaction }\end{array}$} & \multicolumn{3}{|c|}{ Mimiviridae } & \multirow[t]{2}{*}{ Marseilleviridae } & \multirow{2}{*}{$\begin{array}{l}\text { Sputnik } \\
\text { virophage }\end{array}$} \\
\hline & & $\mathrm{A}$ & B & $\mathrm{C}$ & & \\
\hline $10^{7}$ & 7.00 & $21.2 \pm 1.29$ & $16.6 \pm 1.36$ & $15.9 \pm 0.17$ & $15.4 \pm 0.33$ & $15.5 \pm 0.16$ \\
\hline $10^{6}$ & 6.00 & $23.8 \pm 0.56$ & $18.7 \pm 0.28$ & $19.0 \pm 0.35$ & $18.7 \pm 0.29$ & $18.7 \pm 0.22$ \\
\hline $10^{5}$ & 5.00 & $27.7 \pm 0.27$ & $22.4 \pm 0.46$ & $22.9 \pm 0.29$ & $22.4 \pm 0.38$ & $22.7 \pm 0.15$ \\
\hline $10^{4}$ & 4.00 & $30.9 \pm 0.24$ & $26.1 \pm 0.25$ & $26.4 \pm 0.3$ & $25.7 \pm 0.57$ & $25.9 \pm 0.26$ \\
\hline $10^{3}$ & 3.00 & $34.0 \pm 0.47$ & $29.3 \pm 0.15$ & $30.1 \pm 0.22$ & $29.3 \pm 0.38$ & $29.4 \pm 0.17$ \\
\hline $5 \times 10^{2}$ & 2.70 & $35.1 \pm 0.35$ & ND & ND & ND & ND \\
\hline $2.5 \times 10^{2}$ & 2.40 & $35.9 \pm 0.29$ & ND & ND & ND & ND \\
\hline $1.25 \times 10^{2}$ & 2.10 & $36.8 \pm 0.66$ & ND & ND & ND & ND \\
\hline $10^{2}$ & 2.00 & $37.9 \pm 0.57$ & $33.9 \pm 0.21$ & $32.6 \pm 0.42$ & $32.8 \pm 0.32$ & $33.7 \pm 0.58$ \\
\hline $6.25 \times 10^{1}$ & 1.79 & $37.9 \pm 0.87$ & $\mathrm{ND}$ & $\mathrm{ND}$ & ND & $\mathrm{ND}$ \\
\hline $5 \times 10^{1}$ & 1.70 & ND & $34.8 \pm 0.45$ & $33.5 \pm 0.48$ & $33.5 \pm 0.59$ & $34.8 \pm 0.36$ \\
\hline $3.12 \times 10^{1}$ & 1.49 & $39.9 \pm 1.43$ & ND & ND & ND & $\mathrm{ND}$ \\
\hline $2.5 \times 10^{1}$ & 1.40 & ND & $36.2 \pm 1.02$ & $34.7 \pm 0.94$ & $34.7 \pm 0.68$ & $36.1 \pm 0.76$ \\
\hline $1.56 \times 10^{1}$ & 1.19 & $41.1 \pm 2.38$ & ND & $\mathrm{ND}$ & ND & $\mathrm{ND}$ \\
\hline $1.25 \times 10^{1}$ & 1.10 & ND & $37.0 \pm 1.07$ & $35.2 \pm 0.89$ & $35.7 \pm 0.61$ & $36.9 \pm 1.22$ \\
\hline 7.81 & 0.89 & $42.2 \pm 1.15$ & ND & ND & ND & ND \\
\hline 6.25 & 0.79 & ND & $37.7 \pm 0.52$ & $35.6 \pm 0.77$ & $36.1 \pm 1.18$ & $37.8 \pm 0.77$ \\
\hline
\end{tabular}

Results are presented as mean Ct values \pm SD. Each concentration point was tested four times for the 1:10 dilutions and ten times for the 1:2 dilutions. ND = Not determined; $\mathrm{SD}$, standard deviation.

Fig. 4. Negative-staining electron micrographs of new mimiviruses isolated from environmental samples following their detection by PCR: virus T1 (a), T2 (b), T3 (c) and T4 (d). Mimiviruses T1 and T2 were isolated from soil samples and mimiviruses T3 and T4 were isolated from water samples.

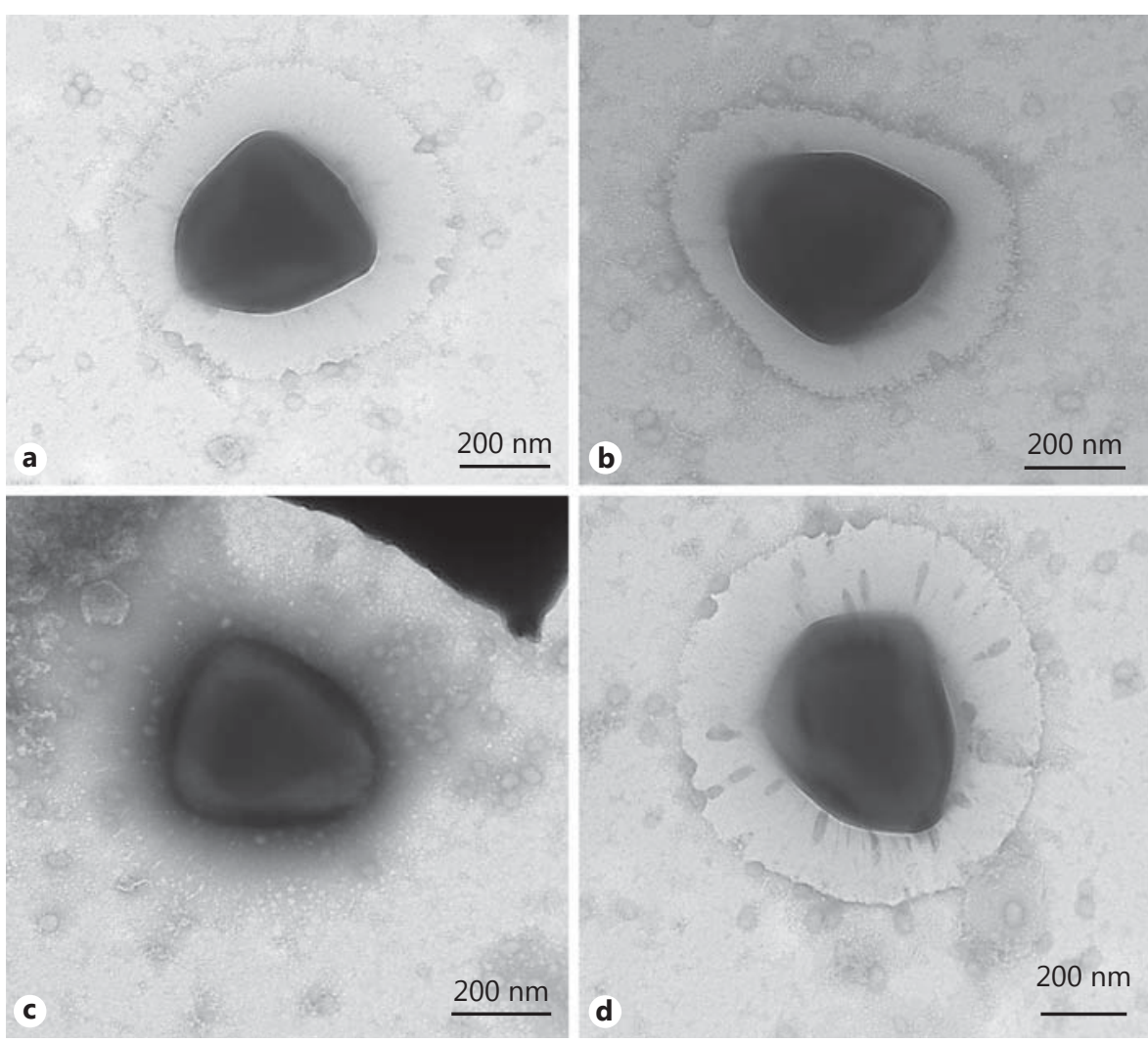

Ngounga/Pagnier/Reteno/Raoult/ La Scola/Colson 
leviruses, with the mean $\mathrm{Ct}$ value being 34.4. All environmental samples tested were negative for mimiviruses from lineages A and B as well as the Sputnik virophages. No PCR amplification signal was obtained for any of the negative controls for each of the PCR systems.

As for the 4 positive samples obtained using real-time PCR, cocultures with amoebae were positive for the presence of giant viruses. In contrast, 4 environmental samples that tested negative in all of the PCR systems did not result in the isolation of the viruses after culture on amoe$\mathrm{ba}(\mathrm{p}=0.03)$. The supernatant from the positive culture assays tested positive by real-time PCR with the exception of one sample. Negative-staining electron microscopy confirmed the presence of giant viruses in each of these samples (fig. 4). Viral particle sizes were approximately 400-500 nm. Sequences of the family B DNA polymerase gene obtained for the viruses isolated in these experiments allowed their classification within amoebae mimiviruses of lineage $\mathrm{C}$.

\section{Discussion}

In this study, we implemented real-time PCR assays that accurately detected all or most of the members of currently delineated lineages of giant viruses infecting acanthamoebae and the Mimivirus virophage, enabling accurate classification of the mimiviruses into lineages A, B or C. Linearity range and detection limit of the assays determined on plasmid DNA were similar to those found by two assays designed to target the genome of the single Mimivirus strain [45]. In addition, we were capable of detecting 4 new mimiviruses directly from environmental samples and correctly classifying these viruses within Mimivirus lineage $\mathrm{C}$, as subsequently confirmed by their isolation by culture on amoebae and partial Sanger sequencing of the family B DNA polymerase gene.

In this study, we used a simple in-house strategy to design PCR primers and probes for real-time PCR. This strategy has been developed because giant viruses of amoebae have large genomes with substantial diversity and the level of collinearity of these genomes can be low in some regions. The present study highlights two potential limits of detecting these viruses in clinical samples using real-time PCR. First, the sensitivity of these assays may be insufficient to enable the further detection of these viruses in various clinical samples that may contain very few copies of viral DNA or PCR inhibitors, including fecal samples. Currently, we do not have an accurate esti- mate of the viral titers that may be encountered in clinical samples and future studies should investigate this issue. It should be noted that the Ct values observed here in the four positive environmental samples were close to the detection limit of the PCR assays. Second, our systems may fail to detect unrecognized or newly discovered viruses or genetic variants of known mimiviruses, marseilleviruses and virophages. The probability of such misdetections of amoebae viruses may increase with the expansion of genetic diversity that will likely be revealed by further studies. Moreover, in the present study we did not consider the divergent members of the family Mimiviridae, which includes Crov and recently reclassified distantly related mimiviruses $[5,11]$. These mimiviruses are known to infect green algae, heterokonts and haptophyta, and have not previously been isolated from clinical samples. The PCR systems described here should be updated to take into account the genomes of amoebae viruses that will be discovered in the future.

Mimiviruses, their virophages and marseilleviruses are increasingly being detected in environmental as well as clinical samples. The possible role of mimiviruses as human pathogens, which is supported by a growing body of evidence, prompt us to intensify our screening of clinical samples $[22,34,39]$. PCR systems such as those implemented here may contribute to improved understanding of the prevalence of mimiviruses and their virophages as well as marseilleviruses in humans, and may be helpful in determining whether the presence of these viruses corresponds to an asymptomatic carrier state or is associated with disease. A future step will consist in implementing multiplex protocols for these real-time PCR systems to reduce the cost and time of analyses. Preliminary tests involving mixing the reagents for the three Mimivirus detection systems in pairs has provided promising results as the sensitivity of the assays was minimally reduced.

\section{Acknowledgments}

We are very grateful to Audrey Ferretti for her technical help.

\section{Disclosure Statement}

The authors declare that there is no potential conflict of interest or financial disclosure. 


\section{References}

1 La Scola B, Audic S, Robert C, Jungang L, de Lamballerie X, Drancourt M, Birtles R, Claverie JM, Raoult D: A giant virus in amoebae. Science 2003;299:2033.

$>2$ Raoult D, La Scola B, Birtles R: The discovery and characterization of Mimivirus, the largest known virus and putative pneumonia agent. Clin Infect Dis 2007;45:95-102.

-3 La Scola B, Campocasso A, N’Dong R, Fournous G, Barrassi L, Flaudrops C, Raoult D: Tentative characterization of new environmental giant viruses by MALDI-TOF mass spectrometry. Intervirology 2010;53:344353.

-4 Arslan D, Legendre M, Seltzer V, Abergel C, Claverie JM: Distant Mimivirus relative with a larger genome highlights the fundamental features of Megaviridae. Proc Natl Acad Sci USA 2011;108:17486-17491.

$\checkmark 5$ Fischer MG, Allen MJ, Wilson WH, Suttle CA: Giant virus with a remarkable complement of genes infects marine zooplankton. Proc Natl Acad Sci USA 2010;107:1950819513.

-6 Boughalmi M, Saadi H, Pagnier I, Colson P, Fournous G, Raoult D, La Scola B: Highthroughput isolation of giant viruses of the Mimiviridae and Marseilleviridae families in the Tunisian environment. Environ Microbiol 2013;15:2000-2007.

7 Pagnier I, Reteno D-GI, Saadi H, Boughalmi M, Gaia M, Slimani M, Ngounga T, Bekliz M, Colson P, Raoult D, La Scola B: A decade of improvements in mimiviridae and marseilleviridae isolation from amoeba. Intervirology 2013;56:354-363.

$>8$ Raoult D, Audic S, Robert C, Abergel C, Renesto P, Ogata H, La Scola B, Suzan M, Claverie JM: The 1.2-megabase genome sequence of Mimivirus. Science 2004;306:1344-1350.

$>$ Colson P, de Lamballerie X, Fournous G, Raoult D: Reclassification of giant viruses composing a fourth domain of life in the new order Megavirales. Intervirology 2012;55: 321-332.

$>10$ Desnues C, La Scola B, Yutin N, Fournous G, Robert C, Azza S, Jardot P, Monteil S, Campocasso A, Koonin EV, Raoult D: Provirophages and transpovirons as the diverse mobilome of giant viruses. Proc Natl Acad Sci USA 2012;109:18078-18083.

-11 Yutin N, Colson P, Raoult D, Koonin EV: Mimiviridae: clusters of orthologous genes, reconstruction of gene repertoire evolution and proposed expansion of the giant virus family. Virol J 2013;10:106.

-12 Desnues C, Boyer M, Raoult D: Sputnik, a virophage infecting the viral domain of life. Adv Virus Res 2012;82:63-89.
13 Boyer M, Yutin N, Pagnier I, Barrassi L, Fournous G, Espinosa L, Robert C, Azza S, Sun S, Rossmann MG, Suzan-Monti M, La Scola B, Koonin EV, Raoult D: Giant Marseillevirus highlights the role of amoebae as a melting pot in emergence of chimeric microorganisms. Proc Natl Acad Sci USA 2009;106: 21848-21853.

14 Thomas V, Bertelli C, Collyn F, Casson N, Telenti A, Goesmann A, Croxatto A, Greub G: Lausannevirus, a giant amoebal virus encoding histone doublets. Environ Microbiol 2011;13:1454-1466.

$>15$ Iyer LM, Aravind L, Koonin EV: Common origin of four diverse families of large eukaryotic DNA viruses. J Virol 2001;75:1172011734.

16 Koonin EV, Yutin N: Origin and evolution of eukaryotic large nucleo-cytoplasmic DNA viruses. Intervirology 2010;53:284-292.

17 Ghedin E, Claverie JM: Mimivirus relatives in the Sargasso sea. Virol J 2005;2:62.

18 Monier A, Larsen JB, Sandaa RA, Bratbak G, Claverie JM, Ogata H: Marine Mimivirus relatives are probably large algal viruses. Virol J 2008;5:12.

19 Claverie JM, Grzela R, Lartigue A, Bernadac A, Nitsche S, Vacelet J, Ogata H, Abergel C: Mimivirus and Mimiviridae: giant viruses with an increasing number of potential hosts, including corals and sponges. J Invertebr Pathol 2009;101:172-180.

20 Kristensen DM, Mushegian AR, Dolja VV, Koonin EV: New dimensions of the virus world discovered through metagenomics. Trends Microbiol 2010;18:11-19.

21 Colson P, Raoult D: Megavirales composing a fourth domain of life: Mimiviridae and Marseilleviridae; in Witzany G (ed): Viruses: Essential Agents of Life. Dordrecht, Springer, 2012.

22 Colson P, La Scola B, Raoult D: Giant viruses of amoebae as human pathogens. Intervirology 2013;56:376-385.

23 La Scola B, Marrie TJ, Auffray JP, Raoult D: Mimivirus in pneumonia patients. Emerg Infect Dis 2005;11:449-452.

24 Greub G, Raoult D: Microorganisms resistant to free-living amoebae. Clin Microbiol Rev 2004; 17:413-433.

25 Colson P, Raoult D: Is Acanthamoeba polyphaga Mimivirus an emerging causative agent of pneumonia?; in Scheld WM, Grayson ML, Hughes JM (eds): Emerging Infections 9. Washington, ASM, 2010.

26 Vincent A, La Scola B, Papazian L: Advances in Mimivirus pathogenicity. Intervirology 2010;53:304-309.

$>27$ Berger P, Papazian L, Drancourt M, La Scola B, Auffray JP, Raoult D: Ameba-associated microorganisms and diagnosis of nosocomial pneumonia. Emerg Infect Dis 2006;12:248255.
28 Raoult D, Renesto P, Brouqui P: Laboratory infection of a technician by Mimivirus. Ann Intern Med 2006;144:702-703.

29 Vincent A, La Scola B, Forel JM, Pauly V, Raoult D, Papazian L: Clinical significance of a positive serology for Mimivirus in patients presenting a suspicion of ventilator-associated pneumonia. Crit Care Med 2009;37:111118

30 Vanspauwen MJ, Franssen FM, Raoult D, Wouters EF, Bruggeman CA, Linssen CF: Infections with Mimivirus in patients with chronic obstructive pulmonary disease. Respir Med 2012;106:1690-1694.

31 Bousbia S, Papazian L, Saux P, Forel JM, Auffray JP, Martin C, Raoult D, La Scola B: Serologic prevalence of amoeba-associated microorganisms in intensive care unit pneumonia patients. PLoS One 2013;8:e58111.

\32 Parola P, Renvoisé A, Botelho-Nevers E, La Scola B, Desnues C, Raoult D: Acanthamoeba polyphaga Mimivirus virophage seroconversion in patients returning from Laos. Emerg Infect Dis 2012;18:1500-1502.

33 Cohen G, Hoffart L, La Scola B, Raoult D, Drancourt M: Ameba-associated Keratitis, France. Emerg Infect Dis 2011;17:1306-1308.

34 Saadi H, Pagnier I, Colson P, Kanoun Cherif J, Beji M, Boughalmi M, Azza S, Armstrong N, Robert C, Fournous G, La Scola B, Raoult D: First isolation of Mimivirus in a patient with pneumonia. Clin Infect Dis 2013; 57:e127-e134.

35 Finkbeiner SR, Allred AF, Tarr PI, Klein EJ, Kirkwood CD, Wang D: Metagenomic analysis of human diarrhea: viral detection and discovery. PLoS Pathog 2008;4:e1000011.

36 Sullivan PF, Allander T, Lysholm F, Goh S, Persson B, Jacks A, Evengard B, Pedersen NL, Andersson B: An unbiased metagenomic search for infectious agents using monozygotic twins discordant for chronic fatigue. BMC Microbiol 2011;11:2.

-37 Lysholm F, Wetterbom A, Lindau C, Darban H, Bjerkner A, Fahlander K, Lindberg AM, Persson B, Allander T, Andersson B: Characterization of the viral microbiome in patients with severe lower respiratory tract infections, using metagenomic sequencing. PLoS One 2012;7:e30875.

38 Zhou J, Zhang W, Yan S, Xiao J, Zhang Y, Li B, Pan Y, Wang Y: Diversity of virophages in metagenomic datasets. J Virol 2013;87:42254236.

39 Colson P, Fancello L, Gimenez G, Armougom F, Desnues C, Fournous G, Yoosuf N, Million M, La Scola B, Raoult D: Evidence of the megavirome in humans. J Clin Virol 2013;57: 191-200.

40 Khan M, La Scola B, Lepidi H, Raoult D: Pneumonia in mice inoculated experimentally with Acanthamoeba polyphaga mimivirus. Microb Pathog 2007;42:56-61. 
-41 Ghigo E, Kartenbeck J, Lien P, Pelkmans L, Capo C, Mege JL, Raoult D: Ameobal pathogen Mimivirus infects macrophages through phagocytosis. PLoS Pathog 2008;4:e1000087.

-42 Lagier JC, Armougom F, Million M, Hugon P, Pagnier I, Robert C, Bittar F, Fournous G, Gimenez G, Maraninchi M, Trape JF, Koonin E, Koonin EV, La Scola B, Raoult D: Microbial culturomics: paradigm shift in the human gut microbiome study. Clin Microbiol Infect 2012;18:1185-1193.

-43 Popgeorgiev N, Boyer M, Fancello L, Monteil S, Robert C, Rivet R, Nappez C, Azza S, Chiaroni J, Raoult D, Desnues C: Marseilleviruslike virus recovered from blood donated by asymptomatic humans. J Infect Dis 2013, Epub ahead of print.

-44 Costa C, Bergallo M, Astegiano S, Terlizzi ME, Sidoti F, Solidoro P, Cavallo R: Detection of Mimivirus in bronchoalveolar lavage of ventilated and nonventilated patients. Intervirology 2012;55:303-305.
45 Dare RK, Chittaganpitch M, Erdman DD: Screening pneumonia patients for Mimivirus. Emerg Infect Dis 2008;14:465-467.

46 Larcher C, Jeller V, Fischer H, Huemer HP. Prevalence of respiratory viruses, including newly identified viruses, in hospitalised children in Austria. Eur J Clin Microbiol Infect Dis 2006;25:681-686.

47 Arden KE, McErlean P, Nissen MD, Sloots TP, Mackay IM: Frequent detection of human rhinoviruses, paramyxoviruses, coronaviruses, and bocavirus during acute respiratory tract infections. J Med Virol 2006;78:12321240.

48 Colson P, Pagnier I, Yoosuf N, Fournous G, La Scola B, Raoult D: 'Marseilleviridae', a new family of giant viruses infecting amoebae. Arch Virol 2013;158:915-920.

49 La Scola B, Desnues C, Pagnier I, Robert C, Barrassi L, Fournous G, Merchat M, SuzanMonti M, Forterre P, Koonin E, Raoult D: The virophage as a unique parasite of the giant Mimivirus. Nature 2008;455:100-104.
50 Colson P, Yutin N, Shabalina SA, Robert C, Fournous G, La Scola B, Raoult D, Koonin EV: Viruses with more than 1,000 genes: Mamavirus, a new Acanthamoeba castellanii mimivirus strain, and reannotation of Mimivirus genes. Genome Biol Evol 2011;3:737742 .

51 Thompson JD, Gibson TJ, Plewniak F, Jeanmougin F, Higgins DG: The CLUSTAL_X windows interface: flexible strategies for multiple sequence alignment aided by quality analysis tools. Nucleic Acids Res 1997;25: 4876-4882.

52 Colson P, Tamalet C, Raoult D: SVARAP and aSVARAP: simple tools for quantitative analysis of nucleotide and amino acid variability and primer selection for clinical microbiology. BMC Microbiol 2006;6:21.

53 Rozen S, Skaletsky H: Primer3 on the WWW for general users and for biologist programmers. Methods Mol Biol 2000;132:365-386. 